At night I went up to the old house tower. It was full of the true histories of spiders, trophies from a war that had clipped a hedge of sons, stray bits of lawn-sports still saying thwack and pock. The moon kept it as her house and below me the slow ratchets of the mansion loosened and whirred. There in the best light, with my candle shadows, I hitched my Belfast linens, English and Indian silks, and showed my starry crotch to the stiff-backed toys and danced for all ye who carry my whoring pride.

\title{
Fanny Hawke Goes to the Mainland Forever
}

Ashblue porcelain, straw dolls, child's rocking-chair, neat farms, boxwood beards, gilded sheaves for prayer, Fanny Hawke of Sherkin Island, Quaker, leaving her boundary stones to marry a Catholic lithographer in Cork City, no one on the new pier to wave her away, neither an Easter visit or Market Day.

Only the hindview of a sleepy fox, its brush

shoving like a sheaf of sense through bushes. Goodbye to the baskets in a judged heap in an angle of the breakfast room, the sun ignoring the Atlantic and leaping alone into the midst of her family, rustle, starch, and grave methods, to that good hypocrisy, goodbye.

Goodbye little brother with your long face. 
Small smooth shells on the great strands come with her on her fingers as nails. She smells the lobster the boatmen found in the ghostly sea when she herself was asleep, waiting while she dreamt for this morning, something spangled and strewn on the lightly grassed dunes, something tart in the air while she walked, banging her skirts.

Come, little Fanny Hawke, into the bosom of us hard Catholics, be an outlaw for us. Bring what you own in a seabox on a true voyage like anything worthwhile, your linens with simplest stitchings, your evening head-cloths, your confident plainness. Be sure that you bring all fresh despite that they have cast you completely

onto the desert and mainland of your love.

Up the century, Fanny, with you, never mind. Look at your elegant son, an improved Catholic squaring up landscapes in his future to paint them as they are like a Quaker.

There is your other son, a scholarship painter, a captain in a war, asthmatic, dying young, all happening even as you set out, oh Fanny. 